\title{
Paying Interest on Deposits at Federal Reserve Banks
}

\author{
Richard G. Anderson, Vice President and Economist
}

I

mplementation of monetary policy by most nations' central banks hinges on setting three interest rates: a lending rate, a remuneration rate, and a policy target rate. The lending rate, also widely referred to as the discount rate or the primary credit rate, is the rate of interest charged to financial institutions by the central bank for collateralized loans. The remuneration rate is the rate of interest paid to financial institutions by the central bank on certain deposits held at the central bank. The policy target rate is the level of an otherwise-market-determined interest rate that the central bank seeks to induce via specific market interventions. Taken together, these rates summarize the price(s) at which central banks provide liquidity to financial markets when they exchange interest-bearing assets that are not media of exchange for deposits at the central bank.

In practice, the policy target rate of most central banks is the one-day (overnight) repurchase (RP) rate on government (Treasury) securities. Generally, the remuneration rate is set below the policy target rate, which, in turn, is set below the lending rate; a frequent pattern is a remuneration rate 25 basis points below and a lending rate 25 basis points above, respectively, the target rate. Historically, the Federal Reserve has not followed this practice-its target has been the overnight federal funds rate. When making cross-country comparisons, note that during periods of economic normalcy the rate of interest on uncollateralized federal funds lending typically exceeds by 10 basis points the overnight RP rate. Before October 2008, the remuneration rate was set at zero (that is, no interest was paid on deposits at Federal Reserve Banks), and the lending rate (discount rate) was set below the policy target rate. ${ }^{1}$ On March 17, 2008, the Federal Reserve adopted a temporary policy, in effect at the time of this writing and to remain in effect until financial market stress abates, that the primary credit rate shall be 25 basis points greater than the target federal funds rate. (In addition, the term of primary credit loans was extended for up to 90 days.)

On October 9, 2008, the Federal Reserve initiated interest payments on deposits at Federal Reserve Banks, as authorized by the Emergency Economic Stabilization Act. Although the act was a response to recent financial market disruptions, paying interest on deposits long had been advocated as a means to "level the playing field" between depository financial institutions subject to statutory reserve requirements and their not- so-encumbered competitors. This argument, today, is moot because the widespread adoption and low-cost availability of retail deposit sweep programs has made statutory reserve requirements a "voluntary tax" in the sense that banks may use such programs to reduce the requirement's burden to near zero. ${ }^{2}$ A second traditional argument for interest payments, however, retains its force-in the absence of binding statutory reserve requirements, interest payments will ease the Open Market Desk's daily task of maintaining the market's federal funds rate close to the desired target level because it reduces, to some extent, variation in banks' holdings of deposits at the Federal Reserve Banks.

\section{"Paying interest on reserves should allow us to better control the federal funds rate."}

\section{—Chairman Ben Bernanke}

Since the inception of interest payments, the Federal Reserve has maintained a two-tier pricing scheme. As of this writing (November 21), the Federal Reserve's remuneration rate on "required" reserve balances-that is, deposits at Federal Reserve Banks used to satisfy statutory reserve requirementsequals the reserve maintenance period's average target federal funds rate, while the remuneration rate on deposits in excess of this amount equals the maintenance period's lowest target federal funds rate. ${ }^{3}$ Previously, between October 6 and November 5, the payment rate on required balances was the maintenance period's average federal funds target minus 10 basis points (approximately equal to the overnight $\mathrm{RP}$ rate on Treasuries). For excess balances, between October 6 and October 22 the payment rate equaled the maintenance period's lowest federal funds rate target less 75 basis points, and between October 23 and November 5 equalled the maintenance period's lowest federal funds rate target minus 35 basis points. In its November 5 press release, the Board of Governors said the most recent changes "would help foster trading in the funds market at rates closer to the FOMC's target federal funds rate," echoing Chairman Bernanke's comments on October 7:

The expansion of Federal Reserve lending is helping financial firms cope with reduced access to their usual sources of 
funding. Recently, however, our liquidity provision had begun to run ahead of our ability to absorb excess reserves held by the banking system, leading the effective funds rate, on many days, to fall below the target set by the Federal Open Market Committee. This problem has largely been addressed by a provision of the legislation the Congress passed last week, which gives the Federal Reserve the authority to pay interest on balances that depository institutions hold in their accounts at the Federal Reserve Banks. The Federal Reserve announced yesterday that it will pay interest on required reserve balances at 10 basis points below the target federal funds rate, and pay interest on excess reserves, initially at 75 basis points below the target. Paying interest on reserves should allow us to better control the federal funds rate, as banks are unlikely to lend overnight balances at a rate lower than they can receive from the Fed; thus, the payment of interest on reserves should set a floor for the funds rate over the day. With this step, our lending facilities may be more easily expanded as necessary. So long as financial conditions warrant, we will continue to look for ways to reduce funding pressures in key markets.

Yet, some questions must be asked about the operation of a market in which the three rates of monetary policy are nearly equal (leaving aside the trivial difference between average and lowest federal funds targets during a reserve maintenance period, and the 25-basis-point premium of the primary credit rate above the target federal funds rate). Market analysts in public reports have noted that federal funds market trading volumes fell sharply after the Federal Reserve initiated interest payments on excess deposits at Federal Reserve Banks. It seems reasonable that trading volume will decrease further, perhaps to zero, as the remuneration, primary credit, and target rates are brought together. However, because the Emergency Economic Stabilization Act only authorizes the payment of interest on deposits at Federal Reserve Banks held by depository financial institutions, the remuneration does not place a floor under the market federal funds rate. At times, a depository institution may wish to sell funds at a lower or higher rate to specific institutions. Also, nonbank institutions ineligible for interest payments may sell federal funds directly to other institutions rather than transfer their balances to an institution that will impose a transactions fee before passing through the interest they would receive from the Federal Reserve. Recent public reports from market analysts show that federal funds, as of this writing, have been trading recently in the range of 0.20 to 0.25 percent, one-quarter of the FOMC's target.

Looking forward, it is likely that setting the remuneration rate at the federal funds target will, indeed, push the measured ("effective") daily federal funds rate closer to the FOMC's target. ${ }^{4}$ But it also seems likely that this change will exacerbate recent sharp decreases in daily trading volume, perhaps risk- ing the long-term viability of the federal funds market itself. Further, this setting might harm long-standing correspondent/ respondent relationships between financial institutions. Historically, the federal funds interbank lending market arose during the 1920s when a Federal Reserve member banker noted that other member banks were borrowing at the discount window while he held non-interest-bearing excess reserve deposits at his Federal Reserve Bank. Sensing a profit opportunity, he risked lending his excess deposit balances to a fellow Federal Reserve member bank. His success was soon emulated by others. These incentives vanish (except for minor frictions) when the three rates of monetary policy coincide.

The experiences of other central banks, and a bit of basic economics, suggest an additional motivation for changing the remuneration rate, beyond that mentioned in the Board's November 5 press release-a smaller gap between the remuneration rate and the target rate may increase sharply banks' willingness to hold deposits with the central bank. In New Zealand, for example, deposits held at the Reserve Bank more than doubled after interest payments began. Federal Reserve programs implemented since the mid-September failure of Lehman Brothers that seek to restore credit activity in the economy's nonbank financial sector have added large amounts of liquidity to financial markets-but most also have caused large increases in the excess deposits held by depository institutions at the Federal Reserve Banks. To the extent that the Federal Reserve seeks to continue and expand such programs in nonbank financial markets, it will be crucial to provide incentives for depository institutions to hold ever-increasing amounts of deposits at the Federal Reserve Banks.

\footnotetext{
${ }^{1}$ Before the Monetary Control Act in 1980, the Federal Reserve furnished paymentrelated services at no charge to its member banks.

${ }^{2}$ See, for example, Richard G. Anderson and Robert H. Rasche, "Retail Sweep Programs and Bank Reserves, 1994-1999," Federal Reserve Bank of St. Louis Review, January/February 2001, 83(1), pp. 51-72; and Richard G. Anderson and Suresh K. Nair, "A Specialized Inventory Problem in Banks: Optimizing Retail Sweeps," Production Optimization and Management Science, May 2008, 17(3), pp. 285-95.

${ }^{3} \mathrm{~A}$ reserve maintenance period is a 14 -day period ending Wednesday during which a depository institution that is subject to the Federal Reserve's statutory reserve requirements must hold sufficient quantities of vault cash and/or deposits at Federal Reserve Banks to satisfy a reserve requirement that is calculated from the institution's deposit liabilities during a corresponding reserve computation period. The reserve computation period is a 14-day period that ends on the Monday that is 30 days prior to the ending date of the reserve maintenance period.

${ }^{4}$ The FOMC sets its target as a desired level of the federal funds rate during a reserve maintenance period. In addition, it desires that the Federal Reserve Bank of New York's Open Market Desk minimize day-to-day volatility in the rate. The "effective" rate is calculated each day as a volume-weighted average of rates paid by federal funds borrowers, as reported to the Open Market Desk by federal funds brokers in New York City.
} 